This work was supported by the Swedish Medical Research Council, the Medical Research Council of the Swedish Life Insurance Companies, the Swedish Society of Medicine, and the Karolinska Institute Foundations.

1 Feusner JH, Slichter SJ, Harker LA. Mechanisms of thrombocytopenia in varicella. Am $\mathcal{F}$ Hematol 1979;7 255-64.

2 Espinoza G, Kuhn C, Viral infection of megakaryocytes in varicella with purpura. Am $\mathcal{F}$ Clin Pathol 1974;61:203-8.
3 Winiarski J. IgG and IgM antibodies to platelet membrane glycoprotein antigens in acute childhood idiopathic thrombocytopenic purpura. Br $\mathcal{F}$ Haematol 1989;73:88-92.

Winiarski J, Ekelund E. Antibody binding to platele antigens in acute and chronic ITP: a platelet membrane ELISA for the detection of anti-platelet antibodies in serum. Clin Exp Immunol 1986;63:459-65.

5 Woods VL, McMillan R. Platelet autoantigens in chronic ITP. Br f Haematol 1984;57:1-4.

6 Asano Y, Itakura N, Hiroishi Y, et al. Viral replication and immunologic responses in children naturally infected with varicelıa-zoster virus and in varicella vaccine recipients. F Infect Dis 1985;152:863-8.

\title{
Is a specialist paediatric diabetic clinic better?
}

\author{
S Bloomfield, J W Farquhar
}

\begin{abstract}
Diabetic control in $\mathbf{8 8}$ children attending three general paediatric clinics was compared prospectively over one year with that of 89 children attending a specialist paediatric diabetic clinic. Glycated haemoglobin $\left(\mathbf{H b A}_{\mathbf{1}}\right)$ concentration and days admitted were significantly lower in the group attending the specialist clinic. This has implications for the organisation of paediatric diabetic services.
\end{abstract}

Diabetic control in many children is not as good as it could be. ${ }^{1}$ It has been suggested that better diabetic control is achieved in children attending specialist paediatric diabetic clinics, ${ }^{2}$ but few objective studies have been done. We have collected, over a one year period, data about diabetic control in children attending a specialist paediatric diabetic clinic in a children's hospital compared with those attending paediatric clinics in three district general hospitals.

\section{Methods}

The diabetic clinic at the Royal Hospital for Sick Children (RHSC) acts as a primary referral centre for children under 16 years in south east Scotland. It is staffed by three paediatricians (two consultants and one senior registrar), one adult diabetologist who facilitates gradual transfer of adolescents to the adult clinics, a dietitian, a full time nurse specialist, and a dental hygienist. There is 24 hour access by telephone to medical or nursing staff for advice and the specialist nurse visits at home as required.

Three general paediatric clinics (A, B, and C) in district general hospitals in central Scotland provide care for diabetic children who are seen by a consultant paediatrician or paediatric registrar. A dietitian is available in all these clinics, and a diabetes nurse specialist who is shared part time with the local adult clinics is sometimes available.

Information about children under 13 years of age on 1 October 1985, and with diabetes of more than three months duration, was obtained prospectively for one year as part of a research project concerning diabetes education. Data included a medical and social profile, methods of diabetic care, diabetic events, anthropometric measurements, and measurement of glycated haemoglobin $\left(\mathrm{HbA}_{1}\right)$ at each visit. (All blood samples for $\mathrm{HbA}_{1}$ were analysed at RHSC by a Corning electrophoretic method; the normal reference range is $4 \cdot 7-7 \cdot 9 \%$. Samples were analysed within one week and remained stable. ${ }^{3}$ )

Data from the three district general hospitals and the RHSC clinic were compared by $\chi^{2}$ or Kruskal-Wallis tests as appropriate, and associations between quantitative and ordinal variables were tested by Kendall rank correlation.

\section{Results}

Comparisons were made at the end of one year (a) between the three general paediatric clinic populations, and (b) for all these three clinics combined (if there was no significant difference between them) with the RHSC paediatric diabetic clinic. Age, duration of disease, age at diagnosis, the number of boys, and social class distribution were similar (table 1). The average time spent with the paediatrician at each clinic visit was 25 minutes at RHSC and approximately 15 minutes in the general clinics.

Children attending the clinic at RHSC were admitted to hospital for significantly fewer days
Department of

Child Life and Health,

University of Edinburgh

$S$ Bloomfield

J W Farquhar

Correspondence to:

Dr S Bloomfield

Child Life and Health,

17 Hatton Place,

17 Hatton Place,
Edinburgh EH9 $1 \mathrm{UW}$.

Accepted 7 September 1989
Table 1 Characteristics of diabetic children $<13$ years of age attending paediatric clinics in district general hospitals $(A, B, C)$ and a specialist paediatric diabetic clinic (RHSC)

\begin{tabular}{|c|c|c|c|c|}
\hline & $\begin{array}{l}A \\
(n=40)\end{array}$ & $\begin{array}{l}B \\
(n=24)\end{array}$ & $\begin{array}{l}C \\
(n=24)\end{array}$ & $\begin{array}{l}\text { RHSC } \\
(n=89)\end{array}$ \\
\hline $\begin{array}{l}\text { Mean (SD) age (years) } \\
\text { Mean (SD) duration diabetes (years) } \\
\text { Male/female } \\
\text { No in social class I and II }\end{array}$ & $\begin{array}{l}10 \cdot 7(2 \cdot 6) \\
4 \cdot 2(2 \cdot 5) \\
16 / 24 \\
13\end{array}$ & $\begin{array}{c}11 \cdot 1(1 \cdot 9) \\
4 \cdot 9(2 \cdot 8) \\
10 / 14 \\
6\end{array}$ & $\begin{array}{l}10 \cdot 2(2 \cdot 4) \\
3 \cdot 3(1 \cdot 7) \\
7 / 17 \\
12\end{array}$ & $\begin{array}{l}10 \cdot 6(2 \cdot 8) \\
4 \cdot 6(2 \cdot 8) \\
39 / 50 \\
32\end{array}$ \\
\hline
\end{tabular}

There was no significant difference between groups for any variable. 
Table 2 Comparison of indices of diabetic control between RHSC and three general paediatric clinics over a one year period

\begin{tabular}{|c|c|c|c|c|c|c|}
\hline & $\begin{array}{l}A \\
(n=40)\end{array}$ & $\begin{array}{l}B \\
(n=24)\end{array}$ & $\begin{array}{l}C \\
(n=24)\end{array}$ & $p$ Value $^{\star}$ & $\begin{array}{l}\text { RHSC } \\
(n=89)\end{array}$ & p Valuet \\
\hline $\begin{array}{l}\text { Mean (SD) No of days admitted/year } \\
\text { No (\%) patients admitted for hypoglycaemia } \\
\text { No (\%) patients admitted for hyperglycaemia } \\
\text { Mean (SD) HbA (\%) } \\
\text { Mean (SD) No of clinic visits/year } \\
\text { Mean (SD) insulin dose (U/kg/24 hours) } \\
\text { No (\%) patients with two injections/day } \\
\text { No (\%) patients with two insulins/day }\end{array}$ & $\begin{array}{l}2 \cdot 7(6 \cdot 8) \\
6(15) \\
7(17) \\
12 \cdot 0(2 \cdot 6) \\
5 \cdot 7(1 \cdot 7) \\
0 \cdot 92(0 \cdot 2) \\
35(87) \\
32(80)\end{array}$ & $\begin{array}{l}3 \cdot 1(6 \cdot 0) \\
0 \\
8(33) \\
12 \cdot 1(3 \cdot 0) \\
6 \cdot 1(2 \cdot 5) \\
0 \cdot 95(0 \cdot 3) \\
11(46) \\
8(33)\end{array}$ & $\begin{array}{l}2 \cdot 4(4 \cdot 4) \\
0 \\
8(33) \\
11 \cdot 2(1 \cdot 9) \\
4 \cdot 3(1 \cdot 6) \\
0 \cdot 90(0 \cdot 2) \\
14(58) \\
23(96)\end{array}$ & $\begin{array}{l}\text { NS } \\
<0.05 \\
\text { NS } \\
\text { NS } \\
<0.001 \\
\text { NS } \\
<0.01 \\
<0.01\end{array}$ & $\begin{array}{l}1 \cdot 2(5 \cdot 8) \\
14(16) \\
3(3) \\
10 \cdot 3(1 \cdot 6) \\
4 \cdot 8(1 \cdot 2) \\
0 \cdot 91(0 \cdot 2) \\
81(91) \\
84(94)\end{array}$ & $\begin{array}{l}<0.05 \\
\text { NT } \\
<0.001 \\
<0.001 \\
\text { NT } \\
\text { NS } \\
\text { NT } \\
\text { NT }\end{array}$ \\
\hline
\end{tabular}

${ }^{\star}$ Comparison between the three general paediatric clinics.

tComparison of the three general clinics combined compared with RHSC clinic

$\mathrm{NT}=$ not tested because of a significant difference when comparing $\mathrm{A}, \mathrm{B}$, and $\mathrm{C}$.

(table 2) and those admitted for poor control and hyperglycaemia were also significantly fewer. There was a significant difference between the three general paediatric clinics in the number of children admitted with hypoglycaemia. Mean $\mathrm{HbA}_{1}$ concentration for the year was similar for children attending each of the general paediatric clinics but significantly lower in those attending the RHSC clinic.

Daily insulin dose was similar for all children but methods of administration differed. Two injections per day were used more by children attending clinic $\mathrm{A}$, and two different insulins per day (that is, short and intermediate acting insulin) as opposed to one insulin per day (intermediate acting) were used more often by children attending clinic $C$. Fewer clinic attendances per year were made by children attending clinic C. Attendance rate at all clinics was greater than $80 \%$. Anthropometric measurements including growth velocities were not significantly different between groups and were within the normal range.

\section{Discussion}

We have observed in diabetic children who were similar in age, duration of diabetes, and social class, that diabetic control was better in those attending a specialist paediatric diabetic clinic than in those attending general paediatric clinics. Control in children attending the general clinics was in fact not dissimilar from that reported previously from another specialist centre. ${ }^{1}$ The introduction of a specialist clinic in East Birmingham where none previously existed resulted in a dramatic improvement in diabetic control. ${ }^{2}$

What are the possible explanations for the better control achieved by the specialist paediatric diabetic clinic? The number of clinic visits to the specialist clinic at RHSC were significantly fewer and the time spent with the doctor was not significantly different in comparison with the general clinics. Access to a paediatrician with a special interest in diabetes may be beneficial, but the diabetes team he leads might be a more important factor. This includes specialist nurses, both in the ward and clinic, whose roles are supportive and educational, a dietitian with specific expertise in diabetes, and a dental hygienist. All play a part in educating and motivating families towards good control and are often more accessible than medical staff.

The standard of control achieved, however, may not be commensurate with the greater resources available in the specialist centre, but the introduction of some aspects of specialist care into district general hospitals-for example, the specialist nurse-and shared care between centres may produce savings in both hospital admissions and future complications. Thus the specialist clinic can act as an advisory, educational, and training resource for other clinics. The annual incidence of insulin dependent diabetes mellitus has almost doubled in a decade in Scotland, ${ }^{4}$ a trend found in most developed countries, ${ }^{5}$ and these young people will place an increasing burden on health care resources. The evidence that good control can reduce future complications is growing, ${ }^{6}$ and their incidence may be reduced if diabetic children can achieve optimal control.

We thank Drs Blair, Barclay, Whyte, McAinsh, and Campbell for permission to study their patients, Miss E Wilkinson and Mrs UL Ursula Grant for extensive help with data collection, and Dr Rob Elton for help with statistical analysis. Dr Susan Bloomfield was funded by a Project Development Grant from the British Diabetic Association.

1 Mann NP, Johnston DI. Total glycosylated haemoglobin $\left(\mathrm{HbA}_{1}\right)$ levels in diabetic children. Arch Dis Child 1982; 57:434-7.

2 Allgrove J. Improved diabetic control in a district general hospital clinic. Arch Dis Child 1988;63:180-5.

3 Moore JC, Bown E, Coutlaw MC, Jelfs R, Holman RR, Turner RC. Glycosylated haemoglobin: comparison of five different methods, including measurement on capillary blood samples. Ann Clin Biochem 1986;23: 85-91.

4 Patterson CC, Thorogood M, Smith PG, Heasman MA, Clerk JA, Mann JI. Epidemiology of type I (insulin dependent) diabetes in Scotland 1968-76: evidence of an dependent) diabetes in Scotland 1968-76: eviden

5 Bingley PJ, Gale GAM. Rising incidence of IDDM in Europe. Diabetes Care 1989;12:289-95.

6 Leslie ND, Sperling MA. Relation of metabolic control to complications in diabetes mellitus. $\mathcal{F}$ Pediatr 1986;108: 491-7. 